\title{
THE EFFECT OF SERVICE QUALITY AND HOSPITAL IMAGE ON PATIENT SATISFACTION (Survey on Outpatients at Saraswati Cikampek General Hospital)
}

Diana Rizqiah Diputri, Abdul Yusuf

Faculty of Economics and Business

Universitas Singaperbangsa Karawang

e-mail: dayputri85@gmail.com

\begin{abstract}
This study aims to examine and analyze the effect of service quality and hospital image on outpatient satisfaction at the Saraswati Cikampek General Hospital. This research was conducted using descriptive and verification methods, namely: collecting, presenting, analyzing and testing hypotheses, and making conclusions and suggestions. The sample in this study amounted to 400 respondents. The results of this study are that there is a strong and direct correlation between Service Quality and Hospital Image. There is a partial effect of Service Quality on Patient Satisfaction of 21.7\%. And the partial effect of the Hospital Image on Patient Satisfaction is 49.5\%, and the simultaneous effect of Service Quality and Hospital Image on Patient Satisfaction is $71.2 \%$, while the remaining $28.8 \%$ is the influence of other variables not examined.
\end{abstract}

Keywords: Service Quality, Hospital Image, Patient Satisfaction

\section{INTRODUCTION}

The development of the business world engaged in manufacturing and services has experienced very rapid growth. Companies are required to create competitive advantage in their business to be able to compete effectively and efficiently. To gain a competitive advantage in the competition, every company must be able to provide quality products or services and good services to consumers from competitors. Kotler and Armstrong (2012) say that quality products and services have an important role in shaping customer satisfaction.
Nowadays, people are getting smarter and more critical, both in thinking and doing an action. The community began to realize that health becomes something very important, because humans will not be able to live properly if not met their health needs. The community tends to demand better and faster health services.

One of the health service facilities is a hospital. Saraswati General Hospital is a type D private hospital. Type D hospital according to the Minister of Health of the Republic of Indonesia number 56 of 2014 concerning Classification and Licensing of Hospital Article 47 that the services provided by Class D 
General Hospitals include at least: medical services, services pharmacy, nursing and midwifery services, clinical support services, non-clinical support services, and inpatient services.

Consumer satisfaction is a requirement that must be met by the company to be able to successfully create and retain customers. According to Kotler and Keller (2016), Customer Satisfaction is a person's feelings of pleasure or disappointment that result from comparing a product or service's perceived performance (or outcome) to expectations. If the performance or experience does not match expectations, then the patient will feel dissatisfied. If according to expectations, the patient will feel satisfied. And if it exceeds expectations, then the patient will feel very satisfied or happy.

Equally important so that services can be delivered well by hospitals is the company's image, because as the quality of the services provided increases, the company's image will also improve. In this case, it is suspected that fluctuations in outpatients visits at Saraswati Cikampek General Hospital were also due to the bad image of Saraswati Cikampek General Hospital for patients. According to Fajar Laksana in Permanasari (2016), the image of a company or brand can change according to the quality of company services provided to its customers. Then according to Ujang Sumarwan (2011), companies that have a good image in the eyes of their customers are companies that can provide good quality service to their customers.
Based on the research background, the problems that will be examined are as follows: 1) How is the Service Quality at the Saraswati Cikampek General Hospital? 2) What is the Corporate (Hospital) Image of Saraswati Cikampek General Hospital? 3) How is patient satisfaction at Saraswati Cikampek General Hospital? 4) How much correlation between Service Quality and Corporate (Hospital) Image at Saraswati Cikampek General Hospital? 5) How much influence partially the Service Quality and Corporate Image on the Outpatient Satisfaction of Saraswati Cikampek General Hospital? 6) How much influence simultaneously Service Quality and Corporate Image on Outpatient Satisfaction of Saraswati Cikampek General Hospital?

\section{LITERATURE REVIEW}

Service quality is a major factor in the strategy that must be carried out by companies engaged in the service sector, because the satisfaction of a consumer can be measured by how the quality of services provided by the company. According to Buchari Alma (2013) explains that: "Service is a service or services provided to consumers in connection with certain products". Definition of service quality (services) according to Wyckof in Fandy Tjiptono (2014) that: "Service quality (service) is the expected level of excellence and control over the level of excellence to meet customer desires".

Based on the explanation above, it can be concluded that service quality is a conformance to customer criteria that are expected to provide benefits based 
on its superiority in relation to a product, if the service received or felt is in accordance with the expected, then the quality is perceived well and can satisfy the customer. Conversely, if what is received is lower than expected, then the quality is perceived poor or unsatisfactory.

According to Swain and Kar (2018), the overall service quality felt by patients about the hospital is a function of the service experience for patients in six main areas consisting of 20 dimensions, namely: 1) Clinical procedure, 2) Quality of outcome, 3) Admission, 4) Discharge, 5) Waiting time, 6) Patient safety/privacy, 7) Billing and price, 8) Follow-up, 9) Ambience, 10) Availability of resources, 11) Accessibility, 12) Food, 13) Staff attitude, 14) Personalised attention, 15) Information availability, 16) Staff competency, 17) Trustworthiness, 18) Staff diversity, 19) Hospital image, 20) Social responsibility.

Company image or brand image is a series of associations perceived by individuals all the time, as a result of direct or indirect experience or a brand (De Chernatony in Fandy Tjiptono, 2011: 10). Kotler and Armstrong (2012: 231) said that "Brand is a name, term, sign, symbol, design, or a combination of these, that identifies the products or services of one seller or group of sellers and differentiates them from those of competitors." According to Ujang Sumarwan (2011) said that: "The image of the company is the consumer's perception of the product and the company itself, both before making a purchase or after purchasing".
Based on the explanation above, it can be concluded that the company's image is the thoughts and beliefs of a consumer towards the company about the product or service, both before making a purchase or after purchasing.

Shirley Harrison in La Ode Sugianto (2016) complete information about the company's image includes the following 4 dimensions: 1) Personality, the overall characteristics of the company that are understood by the target public such as companies that can be trusted, companies that have social responsibility. 2) Reputation, things that have been done by the company and are believed to be the target public based on the experience of themselves or other parties such as the security performance of a bank transaction. 3) Value, Values owned by a company in other words, corporate culture such as the attitude of management who cares about customers, employees who are responsive to customer requests and complaints. 4) Corporate Identity, components that facilitate the introduction of public targets on companies such as logos, colors and slogans.

Increasingly tight competition in the business world, where each producer competes with one another in an effort to meet the needs of consumers. This requires that every company must be fully oriented to customer satisfaction the main objective of the marketing process. According to Kotler and Keller (2016) that, "Customer Satisfaction is a person's feelings of pleasure or disappointment that results from 
comparing a product or service's perceived performance (or outcome) to expectations." Meanwhile, according to Tse and Wilson in Fandy Tjiptono (2011) said that customer satisfaction is the customer's response to the evaluation of discrepancies (perceived disconfirmation) between the previous expectations (or other performance norms) and the actual performance of the product felt after its use.

Based on the expert opinion above, it can be concluded that customer satisfaction is the level of feeling felt by consumers in relationships after using, using, feeling, and consuming goods or services. Customer satisfaction lies in the company's ability to understand the needs, desires and expectations of customers so that the delivery of products, both goods and services by the company in accordance with customer expectations.

The dimensions of customer satisfaction (patients) According to Kennedy and Young in Metha Aryska (2017), there are four dimensions of customer satisfaction measurement in the service sector, namely: 1) Avaibility is the level of existence where customers can easily find the party giving service. 2) Responsiveness, which is the level to which service providers react quickly to customer requests. 3) Convinience, which is the level at which service providers display appropriate professional behavior and style while working with customers. 4) Timelines, i.e. the level at which work can be carried out within a period according to the agreement.

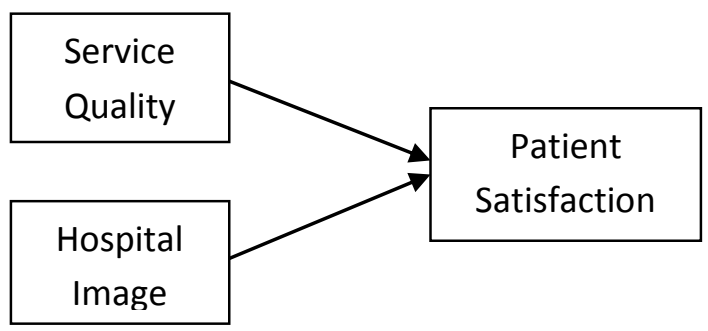

Figure 1. Research Framework

\section{METHOD}

This research was conducted on outpatients at the Saraswati Cikampek General Hospital. The target population in this study is outpatients Saraswati Cikampek General Hospital, recorded in January-August 2018 as many as 17.525 patients. The type of data used by researchers in research on the Effect of Service Quality and Hospital Image on Outpatient Satisfaction at Saraswati Cikampek General Hospital are primary and secondary data.

The sampling technique in this study used incidental sampling with the number of samples using the Slovin formula obtained as many as 400 respondents. This research uses Multiple Regression Analysis techniques. Regression analysis is a 
statistical procedure to analyze the relationship between dependent and independent variables.

\section{RESULT AND DISCUSSION}

This section presents statistical results concerning the effect of service quality and hospital image on patiet satisfaction, with the results of research that has been processed by the computer through the SPSS program with multiple regression analysis partially and simultaneously.

Table 1. Results of Multiple Regression Analysis

\begin{tabular}{|c|c|c|c|c|c|}
\hline \multirow[b]{3}{*}{ Model } & \multicolumn{2}{|c|}{ Coefficients $^{\mathrm{a}}$} & \multirow[b]{2}{*}{$\begin{array}{l}\text { Standardized } \\
\text { Coefficients }\end{array}$} & \multirow[b]{3}{*}{$\mathrm{T}$} & \multirow[b]{3}{*}{ Sig } \\
\hline & & $\begin{array}{l}\text { dardized } \\
\text { ficients }\end{array}$ & & & \\
\hline & B & Std. Error & Beta & & \\
\hline $\mathrm{l}($ Constant $)$ & $-1,557$ & 1,443 & & $-1,079$ & ,281 \\
\hline Service Quality & ,175 & ,025 & ,289 & 6,895 & ,000 \\
\hline Hospital Image & 654 &, 046 & 601 & 14,316 & 000 \\
\hline
\end{tabular}

a. Dependent Variable: Kepuasan Pasien

Based on the results of the regression analysis, a multiple regression equation can be formulated as follows: $\quad Y=0,289 X_{1}+$ $0,601 X_{2}+p y \varepsilon_{1}$

From Table 1, then partially each independent variable influences customer satisfaction. With the following coefficients: $a_{1}=$ The path coefficient that illustrates the magnitude of the direct effect of $X_{1}$ on $\mathrm{Y}, a_{2}=$ The path coefficient which illustrates the magnitude of the direct effect of $X_{2}$ on $\mathrm{Y}, \mathrm{Y}=$ Customer satisfaction $p y \varepsilon_{1}=$ Other variables that are not measured, but affect.

Table 2. Effect of Service Quality $\left(X_{1}\right)$ and Hospital Image $\left(X_{2}\right)$ on Patient

\begin{tabular}{|c|c|c|c|c|c|}
\hline \multicolumn{6}{|c|}{ Satisfaction (Y) } \\
\hline \multirow[t]{2}{*}{ Variabel } & \multirow{2}{*}{$\begin{array}{c}\text { Path } \\
\text { coeffi } \\
\text { cient }\end{array}$} & \multirow{2}{*}{$\begin{array}{l}\text { Direct } \\
\text { Effects }\end{array}$} & \multicolumn{2}{|c|}{ Indirect Effects } & \multirow[t]{2}{*}{ Sub Total Effects } \\
\hline & & & $X_{1}$ & $X_{2}$ & \\
\hline Service Quality $\left(X_{1}\right)$ & 0,289 & 0,084 & --- & 0,133 & 0,217 \\
\hline Hospital Image $\left(X_{2}\right)$ & 0,601 & 0,361 & 0,133 & --- & 0,495 \\
\hline Total of Effects & & & & & 0,712 \\
\hline \multicolumn{5}{|c|}{ Other effects outside the model $1-0,712$} & 0,288 \\
\hline
\end{tabular}

Table 2 shows that the variable Service Quality has an influence on the variable Patient Satisfaction of 0.217 or of 21.7\%. Meanwhile, the variable hospital image has an influence on the variable patient satisfaction by 0.495 or by $49.5 \%$. The overall path analysis test results can be described as shown in the table below: 
Table 3. Coefficient of Determination Model Summary

\begin{tabular}{lllll} 
& \multicolumn{3}{c}{ Model Summary } \\
& & & & Std. \\
& & & & Error of \\
& & $\mathrm{R}$ & Adjuste & the \\
Mo & & Squar & d R & Estimat \\
del & $\mathrm{R}$ & $\mathrm{e}$ & Square & $\mathrm{e}$ \\
\hline 1 &, $844^{\mathrm{a}}$ &, 712 &, 710 & 3,025
\end{tabular}

Based on Table 3 above, it can be seen that the coefficient of determination of service quality and hospital image of patient satisfaction is 0.712 or $71.2 \%$. This means that the Service Quality and Hospital Image has an influence on Patient Satisfaction of $71.2 \%$ while the remaining $28.8 \%$ is the influence of other variables not examined. Partial test in this study can be seen by looking at the $T$ value in the results of statistical calculations using SPSS in Table 1 above. The following explanation of the $\mathrm{T}$ value in table 1 .

For the partial influence of Service Quality on Patient Satisfaction with a significant level $(\alpha)=5 \%$ degree of freedom $(\mathrm{df})=(400-2)=397$ earned the value of sig. $(0,000)<\alpha(0,05)$ and $t_{\text {hitung }}(6,895)>t_{\text {tabel }}(1,966)$ then $H_{0}$ is rejected. Thus it can be concluded that Service Quality partially influences on Patient Satisfaction.

The effect of hospital image partially on patient satisfaction with a significant level $(\alpha)=5 \%$ degree of freedom $(\mathrm{df})=(400-2)=397$ earned the value of sig. $(0,000)<\alpha(0,05)$ and $t_{\text {hitung }}(14,316)>t_{\text {tabel }}(1,966)$ then $H_{0}$ is rejected. Thus it can be concluded that the hospital's image partially influences patient satisfaction.
Effect of Service Quality $\left(X_{1}\right)$ and Hospital Image $\left(X_{2}\right)$ simultaneously on patient satisfaction (Y) with a significant level $(\alpha)=5 \%$ degree of freedom $(\mathrm{df})=(400-2)=397$ earned $t_{\text {tabel }}=1,966$. While, $f_{\text {tabel }}=$ as follows: 3.02 , then $f_{\text {hitung }}$ can be seen in the following table:

Table 4. Calculation Result of F Value $\mathrm{ANOVA}^{\mathrm{b}}$

Mean

\begin{tabular}{|c|c|c|c|c|c|}
\hline Model & $\begin{array}{l}\text { Sum of } \\
\text { Squares }\end{array}$ & $\mathrm{df}$ & $\begin{array}{c}\text { Squar } \\
\mathrm{e}\end{array}$ & $\mathrm{F}$ & Sig. \\
\hline Regr & 8961 & 2 & $\begin{array}{r}4480 \\
815\end{array}$ & $\begin{array}{r}489, \\
742\end{array}$ & $\begin{array}{l}, 000 \\
\mathrm{a}\end{array}$ \\
\hline Res & 3632 & 397 & 9,149 & & \\
\hline Total & 12593 & 399 & & & \\
\hline
\end{tabular}

In Table 4 above, show the sig value. $(0,000)<\alpha(0,05)$ and $f_{\text {hitung }}$ $(489,742)>f_{\text {tabel }}(3,02)$ then $H_{0}$ is rejected. Thus it can be concluded that Service Quality $\left(X_{1}\right)$ and Hospital Image $\left(X_{2}\right)$ simultaneously affect patient satisfaction (Y).

Based on the results of research and discussions that have been carried out, the results of the analysis can be seen that there is a significant influence between Services Quality and Hospital Image at Saraswati Cikampek General Hospital. Significant influence shows that the better quality of service provided by Saraswati Cikampek General Hospital will increase patient satisfaction. This research was supported by Ika Selvia Umayya NST (2017) who stated that Service Quality has a significant effect on patient satisfaction. This research is also 
supported by Kotler and Keller's (2016) theory which states that: "Product and service quality, customer satisfaction, and company profitability are three things that are closely related. The higher the level of quality, the higher the level of customer satisfaction generated, which supports higher prices and (often) lower costs ".

The results of the analysis partially have a significant effect between the hospital image on outpatient patient satisfaction at the Saraswati Cikampek General Hospital. This shows that the better the image of the hospital will increase the satisfaction of outpatients Saraswati Cikampek General Hospital. This research is supported by the results of previous research conducted by Permanasari (2016) which results show that there is a significant influence between the Company's Image on Customer Satisfaction at Honda Kumala Karawang. The results of this study are also supported by the theory put forward by Buchari Alma (2013) which states that a company that has a good image of its customers can influence the satisfaction of the customers themselves.

Based on the results of research analysis with the F test shows that there is a simultaneous influence between the quality of service and the image of the hospital on patient satisfaction at the Saraswati Cikampek General Hospital. This shows that with the change or the better Quality of Hospital Services and Image, the Outpatient Satisfaction at Saraswati Cikampek General Hospital will increase. The results of this study are supported by research conducted by Permanasari (2016) which results show that there is a significant influence between Service Quality and Company Image on Customer Satisfaction at Honda Kumala Karawang. The results of this study are also supported by the theory put forward by Wyckof in Fandy Tjiptono (2011) Service Quality is the expected level of excellence and control over these advantages to meet customer desires. Furthermore According to Rambat in Permanasari (2016), when customers feel satisfied by a product or service, the image of the product or service will increase.

\section{CONCLUSIONS}

Based on the results of the study and discussion the effect of service quality and hospital image on Patient Satisfaction in Outpatients at the Saraswati Cikampek General Hospital, then a number of things the authors can conclude are the results of the study: 1) The Service Quality at the Saraswati Cikampek General Hospital is at the criteria agree, it shows that the patient has valued the services that have been provided by Saraswati Cikampek General Hospital. 2) The image of Saraswati Cikampek General Hospital is in the criteria of agreeing, it shows that the patient has considered good the Image of Saraswati Cikampek General Hospital. 3) Patient satisfaction is in the agreed criteria, it shows that the patient is satisfied with the Saraswati Cikampek General Hospital. 4) There is a strong correlation between Service Quality and Hospital Image. This shows that the Service Quality can improve the Hospital image of Saraswati Cikampek General Hospital. 5) Partially the Service Quality and 
Hospital Image significantly influence the Outpatient Satisfaction of Saraswati Cikampek General Hospital. Then, Hospital Image has a higher influence on Patient Satisfaction at Saraswati Cikampek General Hospital. 6) The of the effect of Service Quality and Hospital Image affect the simultaneous patient satisfaction with an effect of $71.2 \%$, while the remaining $28.8 \%$ is influenced by other variables not examined in this study.

\section{REFERENCES}

Alma, Buchari. 2013. Manajemen Pemasaran dan Pemasaran Jasa. Edisi Revisi, Cetakan 10. Bandung: Alfabeta.

Aryska, Metha. 2017. "Pengaruh Reputasi Perusahaan dan Kualitas Pelayanan Terhadap Kepuasan Pasien (Kasus Rumah Sakit Islam Ibnu Sina Pekanbaru)". JOM FISIP 4(1) : 1

Kotler, Philip \& Kevin Lane Keller. 2016. Marketing Management. E disi ke-15e Global Edition.United state of America: Pearson

Kotler, Philip and Gary Amstrong. 2012. Principles Of Marketing. Global Edition. 14 Edition. New Jersey: Pearson Education.

Regulation of the Minister of Health of the Republic of Indonesia Number 56 Year 2014 Hospital Classification and Licensing. September 1, 2014. State Gazette of the Republic of Indonesia Year 2014 Number 1221. Jakarta.
Sugianto, La Ode. 2016. "Antecedent And Konsekuen Word Of Mouth". Jurnal Ekonomi Syariah 4 (1): $155-178$

Sumarwan, Ujang. 2011. Perilaku Konsumen. Jakarta: Penerbit PT Ghalia Indonesia

Swain, Swapnarag Swain dan Nirmal Chandra Kar. 2018. "Hospital service quality as antecedent of patient satisfaction - $a$ conceptual framework". International Journal of Pharmaceutical and Healthcare Marketing. Online at: //doi.org/10.1108/IJPHM-062016-0028

Tjiptono, Fandy. 2011. Manajemen \& Strategi Merk. Yogyakarta: Andi Offet

Tjiptono, Fandy. 2014. Pemasaran Jasa - Prinsip, Penerapan, dan Penelitian. Yogyakarta: Andi Offet

Umayya, Ika Selvia. 2017. Pengaruh Kualitas Pelayanan, Harga Dan Fasilitas Terhadap Kepuasan Pasien Pada Klinik Dokter Gigi Eka Adhayani Aksara Medan. Skripsi. Sumatera: Universitas Islam Negeri Sumatera Utara

Permanasari, Eka Wira. 2016. Pengaruh Kualitas Pelayanan dan Citra Perusahaan Terhadap Kepuasan Pelanggan (Studi Kasus Pada Pelanggan Honda Kumala Karawang). Skripsi. Karawang: Universitas Singaperbangsa Karawang 